\title{
Impact of Entrepreneurship, Vocational and Technical Education on NCE Graduating Students to be Self-employed in Some Selected COE in the North East, Nigeria
}

\author{
USMAN HARUNA \\ Dr. Dabo Baba Hammad \\ Garba Sankira Babayo \\ Yakubu Muhammed Aitami
}

\begin{abstract}
Entrepreneur education was introduced into higher institutions curriculum to expose students to various trades that students will be willing to engage after graduation to reduce unemployment to a bearable rate in the country. It's on this premise that this research is set to assess the Impact of Entrepreneurship and Vocational and Technical Education (VTE) on NCE Graduating students to be self-employed in three selected Colleges of Education in the North East, consisting of Aminu Saleh College of Education Azare Bauchi state, Federal College of Education (technical) Potiskum, Yobe State and Federal College of Education (technical) Gombe, Gombe State. The objectives of the study being to; assess whether entrepreneurship and VTE education has equipped graduating students with needed business skills that would make them self-employed and Whether the personality traits of graduating students have impact on their willing to become self-employed. Based on this, research questions and hypotheses were formulated. The population of the study comprises NCE graduating students of the three teacher training institutions in the north eastern part of the Nigeria. The methodology employed is survey design where copies of self - administered questionnaires with five points Likard scale was administered to the graduating students through combine simple and stratified random technique. Descriptive statistics: simple percentage, mean and standard deviation were used to answer the research questions raised, while chi-square statistics was used to test the two hypotheses formulated. The findings of the study shows that, NCE graduating students believes that entrepreneurship education and VTE courses equipped the graduated students of School of VTE with needed business skills that would make them self-employed and, Students' personality traits have a clear association on the present employment status of graduating students. It was recommended among others that Government at State and Federal level should come up with programs that would provide practical training to graduating students to argument the theory leant in the class and provide them with resources (financial and/or otherwise) to enhance their skills in planning, starting and managing a small business under a close supervision.
\end{abstract}

Keywords: Entrepreneurship, education Vocational, Self-employed, Graduating

DOI: $10.7176 / \mathrm{EJBM} / 11-30-06$

Publication date:October $31^{\text {st }} 2019$

\subsection{Introduction}

The introduction of entrepreneurship education as a compulsory course in all Nigerians tertiary institutions is aimed at exposing/empowering youth graduates to entrepreneurial skills that would make them self-reliance and employer of labour to stimulate Nigerian economy (Chuma, Pearl \& Chizoba 2013, Kostoglou \& siakas, 2012). Bette, (2012) One of the goals of such education is to "acquire both physical and intellectual skills which will enable individuals to be self-reliant and useful members of the society". Article 64(c) of the same section indicates that Universities education shall contribute to: making all students, as part of a general program of all-round improvement in University education, to offer general study courses such as history of ideas, philosophy of knowledge and nationalism. This provision demands the strengthening of entrepreneurship education curriculum in the tertiary institutions.

Looking at the poor nature of north east region, and devastation course by the activities of insurgents, this informed the researchers to examine the entrepreneurship education provided in the teacher training institutions where the majority of the people hit by insurgency took refuge. In the recent years stakeholders in education have gear interest toward entrepreneurship policy and economic strategies that made graduating students self-employed thereby reducing unemployment to bearable rate. Interestingly, both academic and public authorities view entrepreneurship as a contributor to economic development would achieve the objectives of industrialization and sustainable economic development in the region and the nation at large (Hytti \& Kuopusjorvi, 2004 cited by Dabale \& Masese, 2014).

Raimi, Akhuemonkhan \& Sofoluwe, (2013) opined that entrepreneurship education is not a new phenomenum in the history of Nigeria. It has always been an age-long tradition, a culture and a habit that has consistency been inherited from one generation to another within different ethnic nationalities that made up Nigeria. Entrepreneurship mind-set is prevalent in the three ethnic nationalities prior to colonialism providing informal 
entrepreneurship education. Encouragement of communal wealth creation and productive use of human resources was the product of informal entrepreneurship education that characterized the Western, Northern and Eastern regions before the introduction of formal entrepreneurship education curriculum in the tertiary institutions in Nigeria (Musa \& Adewale, 2015).

The need for formal entrepreneurial mind-set in the Nigeria tertiary institutions has arisen mainly as a result of inability of government to provides quality jobs to our teaming graduates (Fasasi \& Etegene,2009). This kind of creation of an environment for stimulation of entrepreneurial behaviour in the academic community is called Academic Entrepreneurship (Kostoglou \& siakas, 2012).

Over the years, most Nigerian youths have graduated from the tertiary institutions wondering what to do next. This is largely, because the jobs for which they have spent their active part of their lives acquiring knowledge and skills are virtually non-existent. The entrepreneurship education was introduced to equip graduating students' with basic entrepreneurial skills in addition to other practical schemes that may be introduce to them, like, the National Youth Service Corps Scheme, the federal government efforts to create two million jobs every year and efforts of other agencies, (Babalala,2007 cited by Fasasi \& Etegene,2009).

\subsection{Statement of the Problem}

Students of Vocational and Technical institutions in Nigeria are expected after graduation to be sound in both theory and skill acquisition that would make them self-reliance. It is on this background that entrepreneurial education introduced in the higher institutions of learning in Nigeria. In recent time, de-cry of high rate of unemployment is at increase, mostly higher institutions graduates. This called for assessment of impact of entrepreneurial education and VTE on the graduates of higher institutions of learning in Nigeria. The introduction of entrepreneurship education ought to have ameliorated problem of unemployment in Nigeria but reverse is the case. The contributions of (Igbatigba, 2007, Fasai \& Atejere 2009, and Fatoki \& Chindoga 2011.) indicated that the curriculum itself and the lecturers do not encourage creativity, innovation and interest in mind of students. One of the obstacles to the success of an enterprise is lack of willingness to take risk. Fear of failure and embarrassment prevent people with ideas not to explore them and venture into a competitive stage.

There are numbers of studies conducted on the impact of entrepreneurship and VTE education on the graduates of higher institutions in Nigeria. For example, Musa and Adewale (2015), Kahinde and Adewuyi, (2015). There is none of these study that focused specifically on school of vocational and technical education of NCE awarding institutions. Thus, this study aimed at fill this Knowledge gap through an empirical study on the Impact of Entrepreneurship, Vocational and Technical Education on NCE Graduates to be self-employed in some Selected COE in the North East, Nigeria

\subsection{Objective of the Study}

The purpose of this paper specifically is to find out the impact of entrepreneurship education on the NCE graduates of school of Vocational and Technical Education to be self-employed. Generally, the authors aimed to investigate:

I. The impact of entrepreneurship education lectures on the graduating students' to be self-employed.

II. Whether the personality traits of graduating students have impact on their willing to become selfemployed.

\subsection{Research Questions}

Based on the objectives, the following research questions were formulated to serve as a guide to accomplish the research work:

I. Whether entrepreneurship education has impact on the graduating students to be self-employed.

II. Are the personality traits of students have impact on their willingness to be self-employed

\subsection{Research Hypotheses}

Based on the objectives and the research questions formulated, the following null hypotheses will be tested:

Ho1: Entrepreneurship education has no significant impact on the graduating students of VTE, to be self-employed. Ho2: personality traits of graduating students do not influence their willingness to be self-employed.

\subsection{Literature Review/Conceptual Framework}

\subsection{Theoretical Framework}

Theory is a fact/law that provides explanation of some aspects of the natural world. Entrepreneurship has many theories formulated by scholars on the field to guide and direct the players to achieve its goals. The study reviewed and based the following as underpinning for the study.

\section{Psychological Entrepreneurship Theories}

Simper (2011) pointed out in his review of empirical study, emphasizing on personal characteristics that define entrepreneurship. These personal characteristics are Personality traits need for achievement and locus of control. 
In his empirical evidence presented three other new characteristics that have been found to be associated with entrepreneurial inclination. These are risk taking, innovativeness, and tolerance for ambiguity.

\section{Personality Traits theory:}

Personality traits are seen as "stable qualities that a person shows in most situations". To the trait theorists there are enduring inborn qualities or potentials of the individual that naturally make him an entrepreneur like qualities of risk-taking, leadership, motivation, and the ability to resolve crises. The characteristics give us a clue or an understanding of these traits or inborn potentials. In fact, explaining personality traits means making inference from behavior.

Kruger (2004) opined that some of the characteristics or behaviors associated with entrepreneurs are that they tend to be more opportunity driven (they nose around), demonstrate high level of creativity and innovation, and show high level of management skills and business know-how. They have also been found to be optimistic, emotionally resilient and have mental energy, they are hard workers, show intense commitment and perseverance, thrive on competitive desire to excel and win, tend to be dissatisfied with the status quo and desire improvement, entrepreneurs are also transformational in nature, who are life long learners and use failure as a tool and springboard. They also believe that they can personally make a difference, are individuals of integrity and above all visionary. He stressed that one the major criticism associated with this trait model is still not supported by research evidence. The only way to explain or claim that it exists is to look through the lenses of one's characteristics/behaviors and conclude that one has the inborn quality to become an entrepreneur.

\section{Locus of Control}

Locus of control is an important aspect of personality. The concept was first introduced by Julian Rotter in the 1950s. Rotter refers to Locus of Control as an individual's perception about the underlying main causes of events in his/her life. In other words, a locus of control orientation is a belief about whether the outcomes of our actions are contingent on what we do (internal control orientation) or on events outside our personal control (external control orientation).

In this context the entrepreneur's success comes from his/her own abilities and also support from outside. The former is referred to as internal locus of control and the latter is referred to as external locus of control. While individuals with an internal locus of control believe that they are able to control life events, individuals with an external locus of control believe that life's events are the result of external factors, such as chance, luck or fate..

\section{Need for Achievement theory}

While the trait model focuses on enduring inborn qualities and locus of control on the individual's perceptions about the rewards and punishments in his or her life, (Kruger, 2004,),posited that need for achievement theory by McClelland (1961) explained that human beings have a need to succeed, accomplish, excel or achieve. Entrepreneurs are driven by this need to achieve and excel.

\section{Conceptual Review \\ 2.2Concept of Entrepreneurship}

Entrepreneurship is the ability to perceive and undertake business opportunities, taking advantage of scares resources utilization. Entrepreneurship is the process of creating something new with value by devoting the necessary time and effect assuming the accompanying finance psychic and social risk and reserving the resulting rewards of monetary and personal satisfaction and independence (Hisrich and Peters, 2002 cited in Evans-Obinna, 2016).

The theoretical history of entrepreneurship, scholars from multiple disciplines in the social sciences have grappled with diverse set of interpretations and definitions to conceptualize this abstract idea. Entrepreneurship is defined by (NCA, study pack, 2014) as the process of creating something different with value, assuming the accompanying financial, psychological and social risks and receiving the resulting social risks and the resulting rewards of monetary and personal satisfaction.

Entrepreneurship is about starting a new business based on a recognized business opportunity as well as operating and maintaining that business. The belief of some people is that entrepreneurship does not need to be taught and therefore, an entrepreneur is born to be so. It should however be noted that for one to be a successful entrepreneur, he/she needs to learn the skills (Griffin and Hammis, 2001 as cited by Odunaike \& Amoda, 2009).

Zimmerer and Scarborough (2006), pointed out that entrepreneurship is a vital tool in improving the standard of living by contributing to, economic development; employment opportunities; reduction in rural-urban drifts; development of local technological base; conservation of foreign exchanges among others.

\subsection{Entrepreneurship Education}

Entrepreneurship education is a form of education that seeks to provide knowledge, skills, attitude and motivation to students for entrepreneurial success in any setting. Entrepreneurship education is that education which assists students to develop positive attitudes, innovation and skills for self-reliance, rather than depending on the government for employment. This will produce graduates with self-confidence and capacities for independent 
thought to discover new information leading to economic development (Emetaron and Obunadike 2008, Oduwaiye,). Entrepreneurship education curriculum in some countries allows students to start real ventures as a formal part of the curriculum (European Commission, 2012). It is believed within the policy circles that from 2006 to 2010 (the first three years of establishing entrepreneurship programme in Nigeria) that at least 50,000 graduates would have gone through entrepreneurship education with sufficient entrepreneurial skills. Out of the projected 50,000 trainees, it is presumed that at least 10,000 graduates would be self-employed and self-reliant by establishing their own business ventures, (Akhuemonkhan, Raimi \& Sofoluwe 2013). Entrepreneurship education has been described as an aspect of both responsive and functional curriculum, (Bette, 2012).

Entrepreneurial education is the purposeful intervention by an adult (the teacher) in the life of a learner to impact entrepreneurial qualities and skills to enable the learner to survive in the world of business (Gouws, 2002). It aims at equipping learners with skills, knowledge and dispositions that can help them develop or implement innovative social or business plans, it said to be education that creates the require manpower and skills necessary for accelerated growth, reduce unemployment and poverty and leverages the human capital that Nigeria is endowed with and empowers more people to participate in unleashing Nigerians potentials. (Oghojafor, Kuye, Sulaiman \& Okonji 2009, Abdulrafiu \& Nura 2017).

It is of great value to state that entrepreneurs were the people whose decisions primarily determined the rate of economic advance. The task of determining how much importance to be attributed to entrepreneurs and how much to the economy in which he works, to the nature of market he supplies to the character of labor supplies and the extent of the natural resources is always difficult (NCA, study pack, 2014). Lack of practical skills by graduates of education system has contributed to the failure of many governments to combat poverty through various poverty reduction programmes initiated (Tope. Otaki \& Margret, 2014, \& Nwabufo \& Joshua, 2015).

Okolie, \& Ogbaekirigwe (2014) defines Entrepreneurship education as that training, which prepare learners to be accountable and innovative persons who become entrepreneurs' thinkers and contribute to development and sustainable communities; it provides opportunities for youths to be experienced, acquire entrepreneurial knowledge, skills, and attitudes including opportunity recognition, idea creation and marshaling resources in face of risk to chase opportunities, venture creation and operation, creativity and critical thinking. It can be deduced from the forgoing definition that, to become self-employed an individual must have acquired saleable entrepreneurship skills and experience.

The fast pace of development recorded in such nations like Malaysia, Indonesia, Brazil and India among others have clearly shown that development is driven by the innovativeness, creativity and enterprise of the people. Unfortunately, Nigeria has not been able to enact similar feats owing to poor linkage between knowledge and development and between the private and public sector of the economy. This may be attributed to late inclusion of entrepreneurial skills in the Nigerian educational system Entrepreneurship education builds the spirit of being entrepreneurs in the minds of the students. Thus, Entrepreneurship education has a way of discouraging laziness and idleness among our teeming population. Most people that are idle today or probably lazy are those that seem to know little or nothing about entrepreneurship. That is, what it takes to develop business plans, start and manage businesses. (Ediagbonya, 2013).

Ojeifo (2012) pointed out that despite numbers of benefits entrepreneurship education offers to the economy, there are still important obstacles that need to be addressed. He observed the following as the major setback to the attainment of education for self-employment:

a) Rampant political and bureaucratic corruption together with the absence of social consensus on important macroeconomic policy issues.

b) Poor access to vocational and skills - development training for rural and urban youths involved in the informal economy.

c) Absence of regulatory mechanisms for effective oversight of enterprise development initiatives, especially those in the MSME space.

d) The presence of administrative and trade barriers that curtail capacity building and inhibit access to technical support.

e) Significant infrastructural deficits (especially with regards to roads and electricity) and systematic irregularities inimical to small businesses.

f) Absence of a pro-active regulatory environment that encourages innovative enterprise development at the grassroots level.

g) No doubt, one of the biggest challenges of any entrepreneur is access to capital.

\subsection{Impact of Entrepreneurship Education on Graduates of Higher Institution in Nigeria}

Entrepreneurship education is vital element to development of any society. Scholars such as (Olorunmolu 2005, Tope. Otaki \& Margret, 2014, Akhuemonkhan, Raimi \&Sofoluwe 2013 \& Ukoha, 2017) agreed that entrepreneurship education/skills is essential in shaping attitude, innovations, willingness to apply necessary capital into the production process, gaining expertise to successfully recognize, start and manage their own 
business to take advantage of existing opportunities. Entrepreneurship knowledge and skills make vital contributions to economic growth. They also stressed that entrepreneurship education is an inevitable strategy for inculcating entrepreneurial culture and orientation in a nation; creating employment; raising individual incomes; and transforming communities to enhance national economic development

Scholars of entrepreneurship in recent years such as (Awan \& Ahmad, 2017) devoted most of their works on assessing the role of entrepreneurship education on the recipients with particular attention on the practicability of the skills acquired for self-reliance, personal attitude, and perceived behavioral control as contributory factors for self-employment. It's on this premise that we also set out to assess the impact of entrepreneurship education on the NCE graduating students of school vocational and technical education. The method and structure of presentation of entrepreneurship education differs from one country to another depending on the level of industrialization and economic advancement.

In USA, entrepreneurship teaching includes "small business management" "new venture creation" and "entrepreneurship" as the commonest name given to courses geared towards inculcating entrepreneurial mindsets in American students. (Solomon, 2008 as cited in Musa \& Adewale 2015). They further stated that, the commonest methods of teaching these courses includes discussions, case studies, guest speakers, business plans and lectures by business owners. Structures for entrepreneurship that would make teaching learning more concrete are put in place, with approximately one-third of colleges and universities having an entrepreneurship centre, and one-third having an entrepreneurship professor.

\subsection{The Role of Vocational and Technical Education in self-employment in Nigeria.}

Vocational and Technical Education (VTE) is fundamental to the development and industrialization of nations. Thus the skills, abilities and competencies that are needed by the nation are embedded in vocational and technical education, which are central to a nation's social and economic emancipation, (Kehinde \& Adewuyi, 2015 \& Olaitan, 1996) highlighted this fact where they observed that apart from individual being the primary beneficiaries of vocational and technical education, the nation stands as fundamental beneficiary to such kind of education.

Adeniyi (2012) described a model of infusing entrepreneurship into vocational and technical education. According to him, this model suggests infusion of entrepreneurial education into vocational and technical education as part of solution to the persistent socio-economic problems, especially unemployment among youths and high incidence of poverty in the country. The need for entrepreneurship education has to be upheld by the society and it calls for reorientation among students and their teachers. This will ensure debunking and unlearning the earlier belief of been employed rather than self-employment after schooling. The government is expected to play a greater role in providing the necessary atmosphere and policy framework for the success of this transformation process. Students while in school will acquire the necessary skills and training, identify an opportunity to exploit and eventual creation of their venture.

The aggregation of individual efforts and emergent of large number of business will promote the economic growth and development in the country and consequently led to reduction in socio-economic challenges. Vincett and Farlow (2008 as cited in Adeniyi, 2012) in their research work identified and suggested some task for educators that are involve in entrepreneurship training and this will go a long way in explaining and clarifying the above mentioned model, viz;

1) Student must have a serious business idea: They are of the opinion that good ideas cannot be invented to order. Normally students were asked to produce a business plan and their assessment is basically rest on that. Therefore, they are urging to provide a realistic guided experience of the entrepreneurial life, which can be done if students are truly committed to their own real ideas and can actually be entrepreneurs not pretending to be so during their course.

2) A formal business plan is not required, but planning itself is important: many studies have argued on the position of business plan. They raised a question on whether formal business plan correlate with business success. According to them "it may even be counterproductive, time consuming and perhaps psychologically diminishing flexibility in the early state of the actual operations". However, several authors described business plan as foundation for business success, and road map or blue print for action and a strategy for avoiding waste of resources, (Fasua, 2006 \& ANAN, study pack, 2014).

3) Insist on extensive, direct student contact with outside community, to validate and optimize the ideas: This explains the need for students to learn in an uncontrolled environment which is far from institutional context through relationship with stakeholders (customer, suppliers and competitors). The students can modify their ideas based on their direct experience outside the university or institution. It is the duty of the educator to make sure that students established contact with outsiders.

4) The number of businesses is limited so as to allow a highly interactive environment: Classroom environment is identified as a key complement of student entrepreneurial workshop. The bulk of classroom time is devoted to students discussing their experiences. It allows free flow of business ideas with diverse concept and experience. It also provides an opportunity for the student to experience the creative intuitive and lateral thinking from various 
people. There was limited research in this aspect of selection of entrepreneurship, but since 1985, there has been an increased interest in entrepreneurial careers in education.

\subsection{Empirical Review}

Similar studies like Afolabi et el (2017) on the Effect of Entrepreneurship Education on Self-Employment Initiatives among Nigerian Science \& Technology Students concluded with the use of regression analysis, the result revealed that entrepreneurship education is a good policy and it has positive effect on selfemployment initiatives.

Musa, \& Adewale, (2015), investigate effects of entrepreneurship education on willingness to own personal business among Nigerian university graduates. The study found that the current structure of entrepreneurship courses in the Nigerian universities is meant to address the issue of graduate unemployment and poverty eradication.it also concluded that method of teaching entrepreneurship education is only restricted to classroom. Izedonmi \& Okafor (2010), assessed The Effect of Entrepreneurship Education on Students' Entrepreneurial Intentions and result revealed that the study makes it clear that entrepreneurial characteristics of youth are diverse and their exposure to entrepreneurship education for a period of four years is capable of provoking the intention of becoming entrepreneurs.

\subsection{Methodology}

\subsection{Research Design}

The methodological approach employed in this study is survey design on NCE graduating students of Vocational and Technical Education, of Aminu Saleh College of Education, Azare Bauchi State, Federal College of Education (Technical) Potiskum and Federal College of Education (Technical) Gombe.in the North East Zone, Nigeria. The purpose of this study is to assess the impact of entrepreneurship and vocational/technical education on graduating students of Vocational and Technical Education to be self-employed. The researchers attempt to find out the impact of entrepreneurship and vocational/technical education after the graduating students has been exposed to various skills acquisition programs of entrepreneurship and vocational/technical education.

\subsection{Population of the study and Sampling Technique}

The targeted population of this study is the graduating NCE students of School of Vocational and Technical Education, College of Education, Azare Bauchi State, Federal College of Education (Technical) Potiskum and Federal College of Education (Technical) Gombe comprising five Schools/Departments namely Agriculture Education, Business Education (Accounting and Secretarial options), Fine and Applied Art Education, Home Economic Education and Technical Education with a total population shown in table 3.1 below Table; 3.1

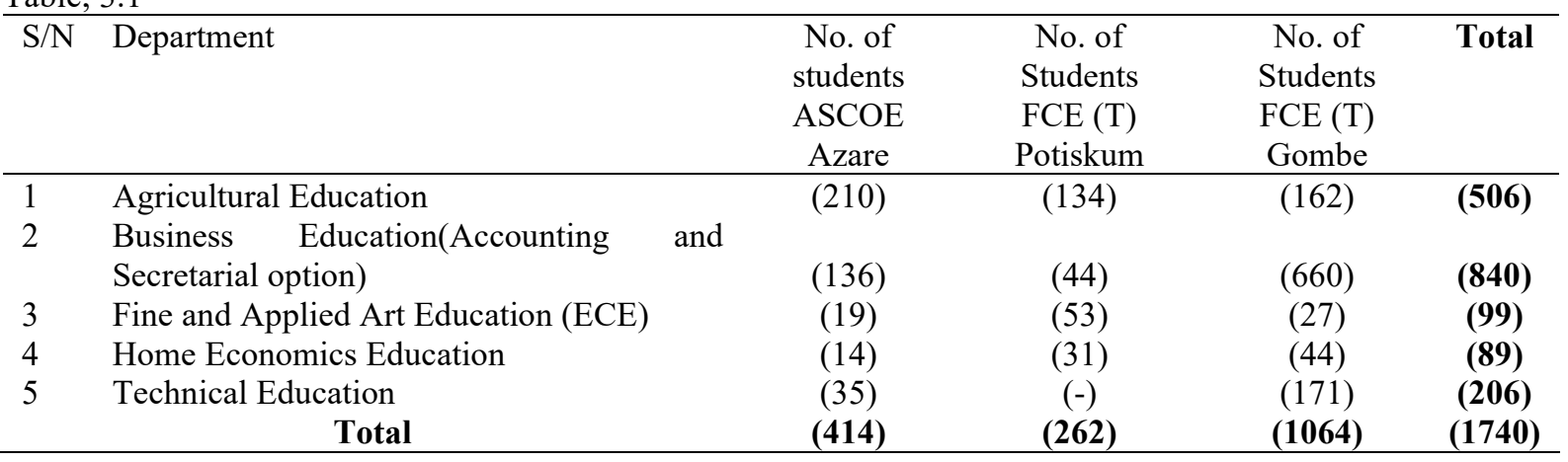

\subsection{Sample and Sampling Technique}

The sample size was determined with the use of Krejcie and Morgan (1970) sampling method table. The population which stood at 1740 this fall between 308 and 322 at $5 \%$ nmargin of error that is, at $95 \%$ confidence level, the range of the two figures is 315 . The research distributes the sample size based on proportion of the population of each institution under study. Simple random techniques were utilized in selecting respondents to respond to the questionnaire items. Structured questionnaires with five points Likard scale (Strongly Agree 'SA', Agree 'A', Neutral, 'N', Disagree, 'D', Strongly Disagree, 'SD') was distributed to elicit data to answer the research questions earlier raised.

\subsection{RESULTS AND DISCUSSION}

In this chapter, the results of the study are presented. Descriptive statistics: simple percentage, mean and standard deviation were used to answer all the two research questions raised in this study, while chi-square statistics was used to test the two hypotheses formulated. 


\subsection{Answering of Research Questions}

Research Question One: Do the entrepreneurship education and VTE courses equipped the graduating students of School of VTE with needed business skills that would make them self-employed?

Table 4.1: Mean and Standard Deviation ratings on whether entrepreneurship education and VTE courses equipped the graduating0 students of School of VTE with needed business skills that would make them selfemployed

\begin{tabular}{|c|c|c|c|c|}
\hline $\mathbf{S} / \mathbf{N}$ & Item statement & $\overline{\mathbf{X}}$ & SD & Remark \\
\hline 1. & $\begin{array}{l}\text { Attendance of entrepreneurship education and practical carried-out add } \\
\text { value to VTE graduates' knowledge and economic competitiveness. }\end{array}$ & 4.32 & 0.87 & Agreed \\
\hline 2. & $\begin{array}{l}\text { NCE graduates who have access to entrepreneurship and VTE education } \\
\text { are better economically empowered than those with no access. }\end{array}$ & 4.10 & 1.04 & Agreed \\
\hline 3. & $\begin{array}{l}\text { VTE graduates need not entrepreneurship education for self-employment } \\
\text { initiatives. }\end{array}$ & 3.51 & 1.43 & Agreed \\
\hline 4. & $\begin{array}{l}\text { Self-employment initiatives and engagement is made possible if the } \\
\text { syllabus of VTE courses are delivered entrepreneurially. }\end{array}$ & 4.00 & 1.04 & Agreed \\
\hline 5. & $\begin{array}{l}\text { Entrepreneurship and VTE education enhances graduates' willingness to be } \\
\text { self-employed. }\end{array}$ & 4.20 & 1.04 & Agreed \\
\hline 6. & $\begin{array}{l}\text { Field trips to Businesses/Companies enhance VTE graduates' knowledge } \\
\text { and provide opportunity to increase interest for self-reliant and sustenance. }\end{array}$ & 4.33 & 0.92 & Agreed \\
\hline 7. & $\begin{array}{l}\text { Entrepreneurship education/ training can stimulate VTE graduates to start } \\
\text { business venture without much or less stress. }\end{array}$ & 4.10 & 0.99 & Agreed \\
\hline 8. & $\begin{array}{l}\text { With the help of VTE courses being skill acquisition in nature and } \\
\text { Entrepreneurship education, starting business to self-employed is made } \\
\text { easier. }\end{array}$ & 4.23 & 0.93 & Agreed \\
\hline 9. & Entrepreneurship education help VTE graduates to become future oriented. & 4.27 & 1.02 & Agreed \\
\hline & Grand Mean & 4.12 & & Agreed \\
\hline
\end{tabular}

KEY: $N=$ Number of sampled nursing mothers, $\overline{\mathrm{X}}=$ Mean, $S D=$ Standard Deviation

Source: Fieldwork, 2019

Information in Table 4.1 presented mean and standard deviation ratings on whether entrepreneurship education and VTE courses equipped the graduating students of School of VTE with needed business skills that would make them self-employed. Table 4.1 revealed that all nine item statements sought to uncover information on this were unanimously agreed upon by the respondents. This is true because the minimum calculated mean value from all the nine items yielded 3.51, while the maximum calculated mean value produced 4.33. These computed mean values are greater than cut-off (3.00) point of five-point scale used in this study. The overall grand mean value for all the nine item statements yielded 4.12 (greater than cut-off of 3.00), showing that NCE graduates believes that entrepreneurship education and VTE courses equipped the graduated students of School of VTE with needed business skills that would make them self-employed. A glance at each of the item statement calculated standard deviation, it can be seen that they are all lower than cut-off point (3.00) explaining that there was closeness in the ratings of respondents (NCE graduates) while responding to the questionnaire.

Research Question Two: Are the graduating students possess personality traits that would enable them sustain the business after being self-employed? 
Table 4.2: Mean and Standard Deviation ratings on whether graduating students possess personality traits that would enable them sustain the business after being self-employed

\begin{tabular}{|c|c|c|c|c|}
\hline $\mathbf{S} / \mathbf{N}$ & Item statement & $\overline{\mathbf{X}}$ & SD & Remark \\
\hline 1. & I want my life to be determined by my own actions & 4.31 & 0.92 & Agreed \\
\hline 2. & When I make plans, I am almost certain to make them work & 4.06 & 1.02 & Agreed \\
\hline 3. & $\begin{array}{l}\text { People like myself have very little chance of protecting our personal interests } \\
\text { when they conflict with those of strong pressure groups }\end{array}$ & 3.82 & 1.20 & Agreed \\
\hline 4. & I feel like what will happens in life is largely determined my powerful people & 4.09 & 1.10 & Agreed \\
\hline 5. & I will spend some time every day developing new idea & 4.21 & 1.03 & Agreed \\
\hline 6. & I will work hard to get what I want & 4.31 & 0.97 & Agreed \\
\hline 7. & $\begin{array}{l}\text { In order to have my plans work I have to make sure that they fit in with } \\
\text { desires of people. }\end{array}$ & 4.03 & 1.09 & Agreed \\
\hline 8. & I give up on things before completing them & 3.89 & 1.20 & Agreed \\
\hline 9. & When I set important goals for myself I rarely achieve them & 4.04 & 1.02 & Agreed \\
\hline 10. & When I decide to do something new I go right to work on it & 4.13 & 1.07 & Agreed \\
\hline 11. & Failure makes me try harder & 4.09 & 1.12 & Agreed \\
\hline 12. & I am a self-reliant person & 4.31 & 0.95 & Agreed \\
\hline 13. & I give up easily & 3.63 & 1.41 & Agreed \\
\hline & Grand Mean & 4.07 & & Agreed \\
\hline
\end{tabular}

KEY: $N=$ Number of sampled nursing mothers, $\overline{\mathrm{X}}=$ Mean, $S D=$ Standard Deviation

Source: Fieldwork, 2019

Information in Table 4.2 revealed mean and standard deviation ratings on whether graduating students possess personality traits that would enable them sustain their business after being self-employed. It was uncovered in the Table 4.2 that the entire thirteen item statements were used to illicit information on this were unanimously agreed upon by the respondents. This is because the minimum calculated mean value from all the nine items yielded 3.63, and the maximum calculated mean value was 4.31. These computed mean values are greater than cut-off (3.00) point of five-point scale used in this study. Similarly, the overall grand mean value for all the 13 item statements yielded 4.07 (greater than cut-off of 3.00), indicating that NCE graduating students possess personality traits that would enable them sustain their business after being self-employed. A glance at each of the item statement calculated standard deviation, it can be seen that they are all lower than cut-off point (3.00) indicating that there was closeness in the ratings of respondents (NCE graduates) while responding to the questionnaire.

\subsection{Testing of Research Hypotheses}

Based on the objectives and the research questions formulated in the study, two null hypotheses were tested using chi-square statistics.

\section{Null Hypothesis One}

Ho1: Entrepreneurship education and VTE courses are independent on the student's employment status

Table 4.3: Chi-Square analysis of Entrepreneurship education and VTE courses on graduating student's employment status

\begin{tabular}{|c|c|c|c|c|c|c|c|c|}
\hline \multirow{2}{*}{$\begin{array}{c}\text { Students' Present } \\
\text { Employment Status }\end{array}$} & \multicolumn{3}{|c|}{ Respondents' Responses } & \multirow[b]{2}{*}{ Total } & \multirow[b]{2}{*}{ df } & \multirow[b]{2}{*}{$\chi^{2}$ crit } & \multirow[b]{2}{*}{$\chi^{2}$ cal. } & \multirow[b]{2}{*}{ Decision } \\
\hline & $\mathbf{A}$ & $\overline{\mathbf{U}}$ & $\bar{D}$ & & & & & \\
\hline \multirow[t]{2}{*}{ Self-employed } & 1 & 14 & 64 & 79 & & & & \\
\hline & $0.4 \%$ & $4.9 \%$ & $22.5 \%$ & $27.8 \%$ & & & & \\
\hline \multirow[t]{2}{*}{ Private employed } & 1 & 13 & 74 & 88 & & & & \\
\hline & $0.4 \%$ & $4.6 \%$ & $26.1 \%$ & $31.0 \%$ & & & & \\
\hline \multirow[t]{2}{*}{ Public employed } & 1 & 2 & 46 & 49 & & & & \\
\hline & $0.4 \%$ & $0.7 \%$ & $16.2 \%$ & $17.3 \%$ & 6 & 2.45 & 10.70 & Dependent \\
\hline \multirow[t]{2}{*}{ Not employed } & 3 & 4 & 61 & 68 & & & & \\
\hline & $1.1 \%$ & $1.4 \%$ & $21.5 \%$ & $23.9 \%$ & & & & \\
\hline \multirow[t]{2}{*}{ Total } & 6 & 33 & 245 & 284 & & & & \\
\hline & $2.1 \%$ & $11.6 \%$ & $86.3 \%$ & $100.0 \%$ & & & & \\
\hline
\end{tabular}

KEY: $A=$ Agreed, $U=$ Undecided, $D=$ Disagreed, $d f=$ degree of freedom, $\chi^{2}$ crit $=$ critical chi-square value, $\chi^{2}$ cal. $=$ calculated chi-square value, $\alpha=$ level of significance,

Source: Fieldwork, 2019 
Information in the Table 4.3 revealed chi-square analysis of entrepreneurship education and VTE courses on graduating student's present employment status. It was uncovered that computed chi-square value (10.70) was greater than critical chi-square value (2.45). Therefore, the null hypothesis two which states that entrepreneurship education and VTE courses is independent on the graduating student's employment status was rejected. This implies entrepreneurship education and VTE courses taught by the lecturers to the students have association with graduating students' present employment status.

\section{Null Hypothesis Two}

Ho2: Personality traits of graduating students of School of VTE are independent on the graduating student's employment status

Table 4.4: Chi-Square analysis of personality traits of students of school of VTE on graduating student's employment status

\begin{tabular}{|c|c|c|c|c|c|c|c|c|c|}
\hline \multirow{2}{*}{$\begin{array}{c}\text { Students' Present } \\
\text { Employment } \\
\text { Status } \\
\end{array}$} & \multicolumn{3}{|c|}{ Respondents' Responses } & \multirow[b]{2}{*}{ Total } & \multirow[b]{2}{*}{ df } & \multirow[b]{2}{*}{$\chi^{2}$ crit } & \multirow[b]{2}{*}{$\chi^{2}$ cal. } & \multirow[b]{2}{*}{$\alpha$} & \multirow[b]{2}{*}{ Decision } \\
\hline & $\mathbf{D}$ & $\mathbf{U}$ & $\mathbf{A}$ & & & & & & \\
\hline \multirow[t]{2}{*}{ Self-employed } & 3 & 16 & 60 & 79 & & & & & \\
\hline & $1.1 \%$ & $5.6 \%$ & $21.1 \%$ & $27.8 \%$ & & & & & \\
\hline \multirow[t]{2}{*}{ Private employed } & 0 & 12 & 76 & 88 & & & & & \\
\hline & $0.0 \%$ & $4.2 \%$ & $26.8 \%$ & $31.0 \%$ & & & & & \\
\hline \multirow[t]{2}{*}{ Public employed } & 0 & 6 & 43 & 49 & & & & & \\
\hline & $0.0 \%$ & $2.1 \%$ & $15.1 \%$ & $17.3 \%$ & 6 & 2.45 & 9.30 & 0.05 & Dependent \\
\hline \multirow[t]{2}{*}{ Not employed } & 2 & 6 & 60 & 68 & & & & & \\
\hline & $0.7 \%$ & $2.1 \%$ & $21.1 \%$ & $23.9 \%$ & & & & & \\
\hline \multirow[t]{2}{*}{ Total } & 5 & 40 & 239 & 284 & & & & & \\
\hline & $1.8 \%$ & $14.1 \%$ & $84.2 \%$ & $100.0 \%$ & & & & & \\
\hline
\end{tabular}

KEY: $A=$ Agreed, $U=$ Undecided, $D=$ Disagreed, $d f=$ degree of freedom, $\chi^{2}$ crit $=$ critical chi-square value, $\chi^{2}$ cal. $=$ calculated chi-square value, $\alpha=$ level of significance,

Source: Fieldwork, 2019

Information in the Table 4.4 uncovered chi-square analysis of personality traits of students of school of VTE on graduating student's present employment status. It is evident that evaluated chi-square value (9.30) is greater than critical chi-square value (2.45). Therefore, the null hypothesis four which states that personality traits of students of School of VTE are independent on the graduating student's employment status was rejected. This implies students' personality traits have a clear association on the present employment status of graduating students. In essence, students' personality traits as potential business tycoon are dependent on present student's employment status.

\subsection{Summary of Research findings}

Based on the data collected ad analyzed from the graduating students across some selected Colleges of Education in the North-East zone, Nigeria, the following findings were uncovered from the study that:

(1) NCE graduating students believe that entrepreneurship education has impact on the graduating students in order to be self-employed.

(2) NCE graduating students believes that entrepreneurship education and VTE courses equipped the graduated students of School of VTE with needed business skills that would make them self-employed

(3) NCE graduating students possess personality traits that would enable them sustain their business after being self-employed

(4) Entrepreneurship education and VTE courses taught by the lecturers to the students have association with graduating students' present employment status

(5) Students' personality traits have a clear association on the present employment status of graduating students

\subsection{Discussion of Findings}

Whenever entrepreneurship education is mention mind is cast on the recipients of such education. Majority of the graduating VTE NCE students that form the population of this study, fall between 22-35 years (age). On the analysis of the results, the calculated mean value (4.24) is affirming the entrepreneurship education has positive impact on the NCE graduating students to be self-employed. This is in line the studies of (Olufemi 2018, Peter 2015), who all posited that, the students are interested in entrepreneurship studies. The students have a positive attitude to start their own business when they graduate. The student demands more practical entrepreneurship. Entrepreneurship education has a positive effect on entrepreneurial intention. Offering entrepreneurship education course is aiding students in development of favorable entrepreneurial attitudes and their intention to start a new venture. 
The result shows that most of the students agree that personality traits have positive relations with entrepreneurial skills that make them self-employed. This is associated with the students examined being vocational and technical oriented.

On the personality trait of the graduating VTE NCE students, the result shows that they possess these traits that can make them future entrepreneurs and sustained themselves after graduation.

This was also asserted in a study conducted by (Oguntimehin, Y.A. and Nwosu, J.C., 2014) title "Building a Sustainable Development Through Entrepreneurship Education in Nigeria" that man is created with certain potentialities with an inbuilt personality traits. The main goal of development is for an environment to display it capabilities and opportunities for present and future generation.

Entrepreneurship Education and VTE expose NCE students to world of work after graduation. As observed in the results and analysis, entrepreneurship, Vocational and Technical courses offered at NCE, prepare students of this type of institution to be able to recognize and start a profitable venture with little resource available to them.

\section{Conclusion}

The study has revealed that entrepreneurship and VTE in the selected NCE awarding institutions have a strong influence in NCE students to be self-employed. The students' develop interest in creation of wealth through entrepreneurial activities, new idea on how to recognize and exploit opportunities, enable them to use their special talents effectively.

Literature reviewed shown that entrepreneurship education has been the effective tools employed globally to minimize unemployment rate. Both developed and developing nations have over the years adopted policies that encourage impacting entrepreneurial skills to younger generation at post primary and higher institutions. The north-east zone has suffered vigorously with activities of insurgency and with entrepreneurship education youth will realized their potentialities rather than engaging in crime that is capable of derailing the zone backward in effect reducing youth unemployment.

\section{Recommendations}

Based on the findings we recommended that entrepreneurship education should dwell more on practical to bust the personal qualities such as creativity, initiative, risk-taking, self-confidence and opportunity recognition. Government at State and Federal level should come up with programs that would provide practical training to graduating students to argument the theory leant in the class and provide them with resources (financial and/or otherwise) to enhance their skills in planning, starting and managing a small business under a close supervision. In addition federal government should introduce youth empowerment packages for North-East zone to revive socio-economic activities in the zone. This would help in diverting the youth mind-set in this zone from insurgency to industrialization.

\section{Reference}

Adeniyi, B. A. (2012); The Role of Entrepreneurship Education in Vocational and Technical Education

Akhuemonkhan, I. A., Raimi, L. \& Sofoluwe, A. O (2013). Entrepreneurship Education and Employment Stimulation in Nigeria; Journal of Studies in Social Sciences (ISSN 2201-4624), 3, (1), pp55-79

Amadi, R. O. \& Adolphus D. (2013);Global Economic Crisis: A Challenge to the Entrepreneurship Development of Technical Vocational Education and Training in Oil and Gas Sector of the Nigerian Economy Journal of Economics and Sustainable Development 4, (12); pp54-61, available Online at: www.iiste.org

ANAN, (2014), PEA 3 Entrepreneurial Development; study Pack: Jos, NCA, Kwall,

Awan, N. N. \& Ahmad N, (2017) Intentions to Become an Entrepreneur: Survey From University Students of Karachi: International Journal of Business, Economics and Law, Vol. 13, Issue 2.

Bette, E. D. (2012),Enhancing the Entrepreneurship Education in Nigeria; American Journal of Social Issues \& Humanities (ISSN: 2276 - 6928), 2(4) pp.232-239 Available online http://www.ajsih.org

Bula O. H. (2012); Evolution and Theories of Entrepreneurship: A Critical Review on the Kenyan Perspective; International Journal of Business and Commerce Vol. 1, No.11: Published by Asian Society of Business and Commerce Research: pp81-96 Available online and retrieved on 19 ${ }^{\text {th }}$ April, 2019 from: https://ijbcnet.com/111/IJBC-12-11106.pdf

Ediagbonya, K. (2013); The Roles of Entrepreneurship Education in Ensuring Economic Empowerment and Development

European Commission, (2012), Effect and Impact of Entrepreneurship Programmes of Higher Education; Brussels.

Evans-Obinna, R. N. (2016), Entrepreneurship Education for Self Reliance and Economic Development in Nigeria: International Journal of Vocational and Technical Education Research Vol.2, No.2, pp.9-14, Published by European Centre for Research Training and Development UK; Retrieved on $12^{\text {th }}$ August, 2018 from: www.eajournals.org

Fatoki O, \& Chindoga L. (2011); An Investigation into the Obstacles to Youth Entrepreneurship in South Africa 
Fasua, K. O., (2006), Entreprenwurship: Theory, Strategies and Practice, Jos: Larigrapnics Printers.

Gouws, E. (2002) "Entrepreneurship Education: Implication for Teacher Training: SATHE/SATHO, 16(2) pp4148

Kehinde, T. M. \& Adewuyi, L. A. (2015); Vocational and Technical Education: A Viable Tool For Transformation of the Nigerian Economy ; International Journal of Vocational and Technical Education Research 1(2) pp.22-31, European Centre for Research Training and Development UK Publisher, available Online at: www.eajournals.org

Kostoglou, V. \& Siakas, E. (2012); Investigating Higher Education Graduates' Entrepreneurship in Greece; Annals of Innovation \& Entrepreneurship. Retrieved on $22^{\text {nd }}$ June, 2016 from: http://creativecommons.org/licenses/by-nc/3.0/.

Kruger, M. E. (2004); Chapter 2: Entrepreneurship Theory and Creativity; university of Pretoria etd; available online and retrieved on $18^{\text {th }}$ April, 2019 from: https://repository.up.ac.za/bitstream/handle/2263/27491/02chapter2.pdf

Musa, M.Y. \& Adewale, R. S. (2015). Effects of entrepreneurship education on willingness to own personal business among Nigerian university graduates. European Journal of Academic Research, 3 (1), 19-30.

Nwabufo, N and Jushua, N. (2015); Entrepreneurship Education: A Panacea for Curbing Graduate Unemployment in Nigeria retrieved $17^{\text {th }}$ April, 2019 from

Odunaike, K. O. \& Amoda, M. B. (2009); Impact of Entrepreneurship Education as a Tool for Self Sustenance at Tai Solarin University of Education, Ijagun, in Ogun State of Nigeria; volume 4,(1)pp49-52 Available online: http://www.medwelljournals.com/fulltext/?doi=sscience.2009.49.52

Oghojafor, B.E.A., Kuye O. L., Sulaiman A.A. \& Okonji P.S. (2009); Empowering Nigerian Youths for National Economic Development: The Role of Entrepreneurship Education; Journal of Research in National Development, $\quad 7(2) \quad p p(-)$ available online http://www.transcampus.org/JORINDV7Dec2009/JournalsV7NO2Dec20092.html

Oguntimehin, Y.A. and Nwosu, J.C. (2014); Building a Sustainable Development Through Entrepreneurship Education in Nigeria; Kuwait Chapter of Arabian Journal of Business and Management Review Vol. 3, No.7; available from: https://www.arabianjbmr.com/pdfs/KD_VOL_3_7/25.pdf

Ojeifo, S. A. (2012); Entrepreneurship Education In Nigeria. Journal of Education and Practice, Vol 3, No 14, retrieved on $17^{\text {th }}$ April, 2019 from: www.iiste.org

Okolie, U. C. \& Ogbaekirigwe, C. (2014); Entrepreneurship Development through Vocational Education Training: Issues and Roles in Skills Acquisition and Manpower Development in a Developing Economy: Journal of Educational Policy and Entrepreneurial Research (JEPER) 1, (2), Pp 151-157 151

Olaitan, S.O. (1996). Vocational and Technical Education in Nigeria (Issues and Analysis). Onitsha: Noble Publishers.

Olorunmolu, J.O. (2008) The Challenges of Entrepreneurship Education Programme in Nigeria: The Perspectives of Millennium Development Goals (MDGs) Sahel Journal of Teacher Education Maiden Edition 1(1) 33-39.

Olufemi A. (2018) The Effect of Entrepreneurship Education on Entrepreneurial Intention among Tertiary Institutions in Nigeria; Journal of Small Business and Entrepreneurship Development December 2018, Vol. 5, No. 2, pp. 1-14; Published by American Research Institute for Policy Development. Available online from: http://jsbednet.com/journals/jsbed/Vol_6_No_2_December_2018/1.pdf

Peter L. (2015); An Analysis of The Relevance of Curriculum Content of Entrepreneurship Development in Higher Educational System in Nigeria. Paper Presented at the 3rd School of Education and Humanities International Conference on the Future of Higher Education in Africa Held at Babcock University August 24-26.

Simpeh K. N. (2011); Entrepreneurship theories and Empirical research: A Summary Review of the Literature; European Journal of Business and Management, Vol 3, No.6, 2011.available online from: https://iiste.org/Journals/index.php/EJBM/article/viewFile/531/417

Tope, A, Otaki, A. O, \& Margret, B. (2014), Entrepreneurship Education: A Panacea to Graduate Unemployment in Nigeria, Journal of Sustainable Development in Africa, 16 (4), pp35-43

Ukoha, U. A. (2017); Assessing Entrepreneurship Education Pedagogies in Three Federal Colleges of Education in Nigeria's South-South Geo-Political Zone; Africa Journal of Teacher Education A Journal of Spread Corporation, Vol.6 No. 1, Pages 1-21

Zimmerer T.W. and Scarborough (2006) Essentials of Entrepreneurship and Small Business Management, New Delhi, Prentice-Hall of India 